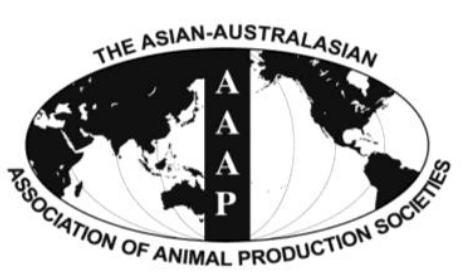

Open Access

Asian Australas. J. Anim. Sci.

Vol. 28, No. 1 : 1-13 January 2015

http://dx.doi.org/10.5713/ajas.14.0001R

www.ajas.info

pISSN 1011-2367 elSSN 1976-5517

\title{
- Invited Review - \\ Characterization of Dietary Energy in Swine Feed and Feed Ingredients: A Review of Recent Research Results
}

\author{
D. E. Velayudhan, I. H. Kim ${ }^{1}$, and C. M. Nyachoti* \\ Department of Animal Science, Winnipeg, Manitoba R3T 2N2, Canada \\ ${ }^{1}$ Department of Animal Resources and Science, Dankook University, Cheonan 330-714, Korea
}

\begin{abstract}
Feed is single most expensive input in commercial pork production representing more than $50 \%$ of the total cost of production. The greatest proportion of this cost is associated with the energy component, thus making energy the most important dietary in terms of cost. For efficient pork production, it is imperative that diets are formulated to accurately match dietary energy supply to requirements for maintenance and productive functions. To achieve this goal, it is critical that the energy value of feeds is precisely determined and that the energy system that best meets the energy needs of a pig is used. Therefore, the present review focuses on dietary supply and needs for pigs and the available energy systems for formulating swine diets with particular emphasis on the net energy system. In addition to providing a more accurate estimate of the energy available to the animal in an ingredient and the subsequent diet, diets formulated using the this system are typically lower in crude protein, which leads to additional benefits in terms of reduced nitrogen excretion and consequent environmental pollution. Furthermore, using the net energy system may reduce diet cost as it allows for increased use of feedstuffs containing fibre in place of feedstuffs containing starch. A brief review of the use of distiller dried grains with solubles in swine diets as an energy source is included. (Key Words: Dietary Energy, Net Energy, Measurement, Distiller Dried Grains with Solubles, Pigs)
\end{abstract}

\section{INTRODUCTION}

Energy is what an animal derives from its food, through the process of cellular respiration which involves a set of metabolic reactions and processes that take place in the cells to convert biochemical energy from nutrients into energy units called adenosine triphosphate (ATP); which is the fundamental "currency" of energy in tissues (Brafield and Llewellyn, 1982; Burrin, 2001; van Milgen and Noblet, 2003). In other words the energy enclosed in the feed as chemical energy is released by partial or complete oxidation following digestive and absorptive mechanisms in the gastrointestinal tract (Pond et al., 1995) and can only be measured in its transformation from one form to another (Kleiber, 1975).

\footnotetext{
* Corresponding Author: C. M. Nyachoti. Tel: +1-204-474-7323, Fax: +1-204-474-7628, E-mail: martin_nyachoti@umanitoba.ca
}

Feed contains ingredients which the animal's body can use as fuel. But even fuel is not yet energy. It depends on the metabolically active components present in the feed such as sugars, fibers, fats and proteins. As per the first and second laws of thermodynamics, all forms of energy are quantitatively convertible to heat (Baldwin and Bywater, 1984) and therefore all measurements of energy are made and conveyed in terms of heat energy or calories (cal) (Armsby, 1917). Although International System of Units measures energy in joules (J), calorie which is a metric system unit of energy, is also widely used in contexts. Calorie can be defined as the amount of heat required at a pressure of one atmosphere to raise the temperature of one gram of water by one degree Celsius (Pond et al., 1995). For diets and feed ingredients, energy content can be expressed as calories (cal), kilocalories (kcal), or megacalories (Mcal) of gross energy (GE), digestible energy (DE), metabolizable energy (ME), or net energy 
(NE) (NRC, 1998).

Majority of the pig's caloric needs are supplied by carbohydrates and fats present in the feed. Carbohydrates are macromolecules consisting of carbon, hydrogen and oxygen $\left(\mathrm{O}_{2}\right)$ atoms. Dietary carbohydrates constitute a major fraction of the diet for pigs and can be divided according to glycosidic linkages into sugars (mono- and disaccharides), oligosaccharides and two broad classes of polysaccharides; starch and non-starch polysaccharides (NSP) (Bach Knudsen and Jorgensen, 2001). The bulk of disaccharides and starch are broken down by the action of pancreatic and mucosal enzymes in the small intestine, while there are no enzymes capable of cleaving some types of oligosaccharides (i.e. $\alpha$-galactosides, fructooligosaccharides) and NSP (Bach Knudsen and Jorgensen, 2001). Therefore, degradation of NSP is performed by the microflora, mainly present in caecum and colon. However, studies have indicated that NSP have a negative effect on the intestinal digestion and absorption process of nutrients (Bakker, 1996). For simple sugars, such as glucose, one mole releases $2.80 \mathrm{MJ}$ of energy equivalent to $3.7 \mathrm{kcal}$ per gram, known as the "caloric content" of sugar which for practical use is taken as $4 \mathrm{kcal} / \mathrm{g}$. Sucrose is composed of two simple sugars, whereas starch consists of several glucose molecules linked together in a linear or branched structure. The cellulose (fiber) is a major component of plant cell wall and is composed of glucose molecules linked together by $\beta 1 \rightarrow 4$ glycosidic bonds, which the pig's digestive tract is unable to unlink them and hence is degraded by microbial fermentation in the hindgut (Bach Knudsen, 2001). Fat molecules, on the other hand, are made almost entirely of carbon and hydrogen, with very little $\mathrm{O}_{2}$ which when metabolized yields approximately 9 $\mathrm{kcal} / \mathrm{g}$, which is more than twice the energy released from carbohydrates. Proteins are very complex molecules containing considerable amount of nitrogen $(\mathrm{N})$ in addition to carbon, hydrogen, and $\mathrm{O}_{2}$. They serve a variety of nutritional needs, but can be metabolized for energy when needed, extracting approximately $4 \mathrm{kcal} / \mathrm{g}$, the same as from carbohydrates. Carbohydrates, protein and fats have an average caloric value of $4.1,5.7$, and $9.4 \mathrm{kcal} / \mathrm{g}$, respectively (Brafield and Llewellyn, 1982; Pond et al., 1995).

\section{ENERGY SOURCES FOR SWINE DIETS}

A single feed ingredient cannot be practically used to supply the animal's requirement for nutrients, since a particular ingredient may be excess of one or more nutrients and be deficient in others. Hence it is always a combination of different ingredients which make up a swine diet. As a result, there has been an intensive effort to quantitatively depict the energy value of the vast array of feed ingredients available for selection in practical swine diets. Pigs have a relatively simple digestive system which makes them inefficient to utilize vast quantities of hay, silage, or pasture grasses. Therefore, swine rations are made up primarily of grains, along with protein supplements and other vitamins and minerals. Cereal grains make up to $50 \%$ to $85 \%$ of the ingredients in swine rations, which in turn provide much of the energy to the animal (Myer and Brendemuhl, 2013). Corn grain is among the leading cereal used in the swine feed industry; which has a greater energy density than other cereal grains. Because of its abundance and high energy concentration, corn is the base to which other cereal grains are compared. Small grains, such as barley, wheat, oats, rye, and triticale form other practical ingredients in swine feeding programs. On many occasions, pigs fed balanced small grain-based diets can perform well compared with those fed corn-based diets (Sullivan et al., 2005). Nutritionally, small grains are comparable to corn in some aspects, but there are variations depending on the grain. The crude protein $(\mathrm{CP})$ in small grains are higher than that in corn especially the lysine which is the first limiting amino acid in cereal grain based swine diets (Sullivan et al., 2005). In addition, small grains have a higher digestible phosphorus level than corn, but tend to be lower in energy content.

With the rise of the ethanol industry, the quantity and availability of grain processing co-products have increased in recent years. Corn distiller dried grains with solubles (DDGS) from the fuel ethanol industry is a major coproduct used in swine feed (Stein and Shurson, 2009). Corn gluten feed and corn gluten meals are co-products of the corn wet-milling industry. The wheat milling co-products include bran and middlings. The nutrient composition of these co-products differs from the original grain source (NRC, 1998).

The chemical composition of the feed ingredient has a major impact on its energy contend. Therefore an accurate estimate of the energy content of each ingredient is necessary for proper diet formulation.

\section{ENERGY METABOLISM}

The term metabolism refers to all "the chemical processes in a living organism by which nutritive material is built up into living matter, or by which complex molecules are broken down into simpler substances during the performance of special functions" (Blakemore and Jennett, 2002).

Metabolism is usually divided into two categories; catabolism and anabolism. Catabolism breaks down organic matter $(\mathrm{OM})$, releasing energy used up in other biochemical reactions or dissipated as heat. Anabolism uses energy to construct components of cells such as proteins and nucleic 
acids and when anabolism exceeds catabolism, it could be defined as growth or weight gain. In a fasting animal, loss of body weight (BW) represents a loss of energy equivalent to fasting heat production (FHP) from the body, while a gain in BW represents energy retention (Blaxter and Boyne, 1978).

\section{ENERGY REQUIREMENTS IN SWINE}

The energy supplied through diets is utilized by the animal for two main functions; maintenance and production. Maintenance functions includes basal metabolism and involuntary activities such as muscle tone, feed digestion, blood circulation, tissues replacement (Wenk et al., 2000; Vestergen, 2001), maintenance of membrane potential and acid-base homeostasis (Baldwin and Bywater, 1984; Milligan and Summers, 1986) along with breaking down of complex chemical substances into simpler form that can be eliminated as waste products from the body. In addition, energy is also necessary to maintain the body temperature irrespective of the environment in which the pig is placed, which is otherwise known as the homeothermal functions (Cole, 1995). At times when thermoregulation, detoxification, immune, fever and stress responses are lacking, energy for maintenance is distributed into four equal proportions for physical activity, cellular ion $\left(\mathrm{Na}^{+}\right.$, $\mathrm{K}^{+}$) transport activity, protein turnover and other maintenance activity like the waste elimination (Verstegen, 2001).

\section{Energy for maintenance}

Maintenance is the requirement of nutrients for the continuity of vital functions within the body so that the net gain or loss of nutrients by the animal as a whole is zero (ARC, 1981). But this definition is not always applicable to growing pigs; wherein they tend to deposit protein at the expense of fat when fed to maintain constant weight (Black, 1974; Campbell, 1988; Wiesemuller et al., 1988; Kolstad and Vangen, 1996). Hence, growing pigs will have an inconsistent energy balance in view of the higher heat of combustion of fat that is lost in exchange for protein gain.

Though the exact measurement of maintenance energy may be complex (van Milgen et al., 2000), it has been extensively adopted by animal nutritionists in an effort to break up the energy cost of maintenance versus that of production and to ease the additivity of the two processes (van Milgen and Noblet, 2003).

These energy requirements for maintenance $\left(\mathrm{ME}_{\mathrm{m}}\right)$ are generally expressed on a metabolic basis, which is defined as $\mathrm{BW}$ raised to the power of $0.75\left(\mathrm{BW}^{0.75}\right)$. However, studies show that the exponent function is significantly less than 0.75 ranging from 0.54 to 0.75 (Tess, 1981). It has been recommended that the appropriate exponent is closer to 0.60 (Noblet et al., 1999) rather than 0.75 as the later underestimates $\mathrm{ME}_{\mathrm{m}}$ for growing pigs (Tess et al., 1984; Thorbek et al., 1984).

\section{Energy for growth}

Once the energy requirements pertaining to maintenance have been fulfilled, the pig can divert the energy to build body tissues (lean and fatty tissues) and grow. During normal growth phase, the first priority of the pig is for lean tissue deposition. Both lean tissue (ham, shoulder, loin, all without subcutaneous fat; Walstra, 1980) and fatty tissue deposition rate increase at a similar pace until the maximum genetic potential for lean growth is reached (Van Lunen and Cole, 2001).

The relationship between energy (feed) intake and tissue growth is that, lean tissue and growth rate respond in a linear fashion to energy intake up to a point where the protein deposition rate is a maximum (Close, 1996; Van Lunen and Cole, 2001). This point corresponds to the genetic capacity of the pig for lean tissue growth. Any additional energy supplied beyond this point will lead to a huge increase in lipid deposition with modest increase in lean, if any. Alternatively, lipid deposition increases at a bigger rate above the 'capacity point' than below it due to the larger proportion of the energy required to fuel protein metabolism below the 'capacity point' (Close, 1996).

\section{ENERGY SYSTEMS FOR SWINE}

Energy being one among the key factors governing the economics in animal production, rigorous efforts has been made to develop methods and systems for assessing the energy content of feed, metabolic utilization of energy and the animal's basic requirements for energy. The principal focus of energy based feed evaluation systems is the amount of energy that can be derived from ingested nutrients to sustain the animal's maintenance and productive functions. The essential qualities of a practical energy system is that they should be precise, should include unconventional rations and high production levels and should be simple to use and applicable in general (Van Es, 1980).

All energy systems follow the common pattern of energy utilization in pigs as has been described in NRC (2012). In most of the practical energy systems, energy value is based on the ability to deposit a certain unit amount of energy in the body per unit amount of extra feed. Energy systems in livestock nutrition are intended for the following basic purposes; to attribute energy values to a feed ingredient or a mixture of feed ingredients that could be used to estimate the amount of a given diet needed to meet the performance of the individual animal (Emmans, 1999) and to determine the requirements for maintenance, 
production, diet formulation and to develop feeding programs. Eventually, the value of such a system lies in its ability to predict the performance of animals (Noblet, 2000).

\section{Gross energy}

Gross energy or heat of combustion is the energy released by burning a sample of feed in excess $\mathrm{O}_{2}$. It is usually determined in an adiabatic bomb calorimeter. As such it provides no information on the amount of that energy that is available to the pig through the digestive procedure or lost during metabolism. So GE is rarely used in feed formulation except for computational purposes.

The GE contend of an ingredient depends upon the amount of carbohydrates, fat and protein it contains. For carbohydrates, the GE value varies since monosaccharides (such as glucose) yield $3.75 \mathrm{kcal} / \mathrm{g}$ and polysaccharides (such as starch) yield $4.16 \mathrm{kcal} / \mathrm{g}$ (Wenk et al., 2000). Likewise, the GE content of protein and fat depends on the amino and fatty acid composition, respectively, with an average of $5.64 \mathrm{kcal} / \mathrm{g}$ for protein (Wenk et al., 2000) and for fat the widely acknowledged GE value is $9.51 \mathrm{kcal} / \mathrm{g}$ (Brouwer, 1965). Consequently if the nutrient composition of feed ingredients and/or diets is known, the GE content can be estimated using existing prediction equations (Ewan, 1989; Noblet and Perez, 1993).

\section{Digestible energy}

Digestible energy is the energy in feed after subtracting the energy lost in feces. Since it is not a true measure of the energy values of the nutrients absorbed from the digestive tract, it is often referred to as apparent digestible energy. Moreover, a small fraction of the energy in feces is supplied by endogenous sources like digestive secretions and intestinal cell debris (Just, 1982).

Digestible energy is usually determined from the GE in the feed consumed and the GE of fecal matter excreted. Alternatively, DE can be measured by mixing nonabsorbable indicators (e.g. acid insoluble ash, chromic oxide or titanium dioxide) into the diet. In pigs, up to $25 \%$ of ingested energy is found in faecal matter (Boisen and Verstegen, 2000); though, for swine diets the digestibility coefficient of energy $\left(\mathrm{DE}_{\mathrm{c}}\right)$ is known to fluctuate between $70 \%$ and $90 \%$, with a much wider variation, $0 \%$ to $100 \%$ for the ingredients (Noblet and Henry, 1993). One of the factors affecting the DE content in pigs includes dietary fiber levels, which is less digestible than other nutrients and reduces the apparent fecal digestibility of other dietary nutrients such as CP and fat (Noblet and Perez, 1993). The animal's ability to digest fiber also varies with the age. Hence DE values obtained from older pigs will overestimate DE values for nursery pigs, especially in feeds with high fiber content (Shi and Noblet, 1993). Fiber is not digested in the small intestine but passes to the large intestine where micro-organisms convert part of the fiber to volatile fatty acids, which are then absorbed. However, digestion in the large intestine is less efficient when compared to direct absorption from the small intestine. In addition, the digestive utilization of fiber is also variable with its botanical origin (Chabeauti et al., 1991).

In studies by Le Goff and Noblet (2001), where apparent energy digestibility was evaluated in growing pigs and adult sows fed the same diets; apparent digestibility was greater in adult sows compared with growing pigs and accordingly, a $4 \%$ greater DE contend was determined. In other terms, although dietary fiber is partly digested by the young growing pig, it supplies very little available energy to the animal (Noblet and Perez, 1993). Thus, it would be relevant to have separate energy requirements for different physiological stages of growth.

\section{Metabolizable energy}

Metabolizable energy could be defined as the GE in the feed minus the GE of the feces (Armsby, 1917), and is estimated as the DE minus urinary energy and gaseous energy $\left(\mathrm{GE}_{\text {gas }}\right.$; mostly $\left.\mathrm{CH}_{4}\right)$. In pigs, the $\mathrm{GE}_{\text {gas }}$ is generally overlooked because it represents only a small fraction of DE, between $0.1 \%$ and 3\% (Verstegen, 1971; Wenk et al., 2000).

In case of sows fed at maintenance level, methane production represents a much higher proportion of DE intake when compared to growing pigs (Noblet and Shi, 1994). In general, methane production increases with pig BW and dietary fiber level. So, depending on the amount of plant cell wall content in the diet and the age of the animal the estimated ME values are usually $0.5 \%$ to $3 \%$ higher than the real value (Van Es and Boekholt, 1987).

Urinary energy losses represent a variable percentage of $\mathrm{DE}$, since the urinary energy is very much dependent on the amount of $\mathrm{N}$ in urine. Urinary $\mathrm{N}$ in turn mainly depends on the amount of digestible protein and for that reason, on the $\mathrm{CP}$ content of the diet. Consequently, the ME:DE ratio is linearly related to dietary protein content (Le Goff and Noblet, 2001). Higher protein levels in diet leads to an increase in the catabolic processes in the animal, and therefore, a greater excretion of urinary $\mathrm{N}$ in protein-rich diets (Morgan et al., 1975). Since the urinary N loss is not accounted for while determining DE, the energy value of protein-rich ingredients is exaggerated with the DE when compared with ME (Morgan et al., 1975). Moreover, the amount of energy in the urine is dependent on the quality and quantity of the protein in the diet relative to requirement (NRC, 1998). By and large, the ME:DE ratio of complete feeds is relatively constant and is equivalent to about 0.96, however, this value is not applicable to individual feed ingredients (Noblet and van Milgen, 2004).

Metabolizable energy is further used to meet different 
energy requirements of the pig namely maintenance, growth, protein or lipid gain, milk production, and so on. There is a marked variation observed in the average efficiency of utilization of $\mathrm{ME}$ for these different purposes: approximately $80 \%$ for fat gain $\left(\mathrm{k}_{\mathrm{f}}\right)$ or maintenance $(\mathrm{km})$, $60 \%$ for protein deposition $\left(\mathrm{k}_{\mathrm{p}}\right), 75 \%$ for weight gain $\left(\mathrm{k}_{\mathrm{g}}\right)$ during growth, and $70 \%$ for milk $\left(\mathrm{k}_{\mathrm{l}}\right)$ (Noblet et al., 1994a).

\section{Net energy}

Net energy is defined as ME minus heat increment (HI) (Birkett and de Lange, 2001). The energy left after such losses is the energy actually available to the animal for maintenance $\left(\mathrm{NE}_{\mathrm{m}}\right)$ and for production $\left(\mathrm{NE}_{\mathrm{p}}\right)$. Heat increment is the heat produced from metabolic utilization of $\mathrm{ME}$ and the energy cost of ingestion, digestion and physical activity (Rijnen et al., 2003; 2004) and is mainly utilized for maintenance of body temperature in cold environments. The energy used for maintenance is also dispersed as heat, so that total HP could be defined as the sum of $\mathrm{HI}$ and $\mathrm{NE}_{\mathrm{m}}$ (NRC, 1998).

The NE content when expressed as a percentage of ME content (k) is otherwise known as the efficiency of utilization of ME for NE (Noblet et al., 1994a). This coefficient is influenced by the ultimate utilization of ME (e.g., maintenance, protein gain vs fat gain vs milk production) and such factors as chemical composition of the feed because the efficiency with which different nutrients are utilized vary (Noblet and van Milgen, 2004; Chudy, 2006). This variations of $\mathrm{k}$, due to differences in efficiencies of ME utilization between nutrients are 90\%, $82 \%, 58 \%$, and $58 \%$ when ME is provided by digestible ether extract (EE), starch, digestible $\mathrm{CP}$ and digestible fiber, respectively (Noblet, 1999). It is because of these differences in the efficiency of utilization that the HI (per unit of energy) is higher when CP and dietary fiber are utilized for energy than it is for starch or EE (Noblet et al., 1994a). Therefore, it is evident that an increase of dietary $\mathrm{CP}$ results in increased HP.

Net energy system could be described as the only system that depicts the energy that is actually available to the pig and this system has been demonstrated to provide a better prediction of pig performance (e.g. Velayudhan and Nyachoti, 2014). Net energy accounts for the differences in metabolic utilization of ME between nutrients; consequently $\mathrm{NE}$ is the only system in which energy requirements of the animal and energy supplied by the diet are expressed on the same basis which is independent of the feed composition (Noblet and Henry, 1993; Noblet and van Milgen, 2004). However, NE is much more difficult to determine and more complex than DE or ME, which may be a reason why it is not as widely used as it should be. In a recent study, it was demonstrated that supplementing pig diets with a multicarbohydrase enzyme may increase the
NE value of the feed and feed ingredient (Velayudhan et al., $2013 b$ ). It will be worthwhile to pursue this further in future studies so to optimize energy utilization under different feeding situations.

\section{HEAT PRODUCTION AND ENERGY RETENTION IN SWINE}

Determination of NE value requires measurement of energy retention or $\mathrm{HP}$ and an estimate of maintenance requirements. As reviewed by van Milgen and Noblet (2003), all ME not retained by the animal is lost as heat. Heat production (HP or the metabolic efficiency of utilizing $\mathrm{ME}$ for NE is dependent on a number of factors including pig genotype (de Lange et al., 2001; Kolstad et al., 2002; van Milgen and Noblet, 2003; Kiarie and Nyachoti, 2010). The retained energy can be measured with the comparative slaughter (CS) technique or by measuring the carbon-N balance and the metabolic processes responsible for the energy supply to the body can be determined by measuring the HP of the animal which can be determined by direct or indirect calorimetry (IC) by measuring the gas exchange from the animal.

\section{METHODS FOR DETERMINING ENERGY RETENTION AND HEAT PRODUCTION}

Energy retention, which is the actual fraction of energy in the feed retained by the body, may be measured by either the CS technique or by carbon-N balance (Adeola, 2001). Though, the CS method involves simple techniques, it is laborious and gives an estimate of the average energy retention over a longer period of time (van Milgen and Noblet, 2003). Heat production may be measured by direct or IC.

\section{Comparative slaughter technique}

Comparative slaughter method is considered as the gold standard for determining the NE content of feeds and has been used in a number of recent studies to determine the NE of swine feed and feed ingredients (Kil et al., 2011; 2013; Ayoade et al., 2012). Determination of body composition of an animal at the beginning and again at the end of a period of time is practically unfeasible (Blaxter, 1989). Hence, the possible alternative would be to determine the body composition of an exactly similar experimental animal at the beginning of the period and at the end of the period (Blaxter, 1989). This method of determining energy retention is termed the CS method. Energy retention is the difference between the body energy contents of the initial and final slaughter groups (Kil et al., 2011; Ayoade et al., 2012). However, the CS method is labor intensive and 
requires a large number of animals. Furthermore, the CS method assumes that the only energy-yielding compounds stored by the body are fat and protein and that these have fixed chemical composition and enthalpies of combustion (Blaxter, 1989).

In the study of Ayoade et al. (2012), NE values of corn soybean meal based diets containing $0 \%, 15 \%$, and $30 \%$ DDGS were estimated to be 2,430,2,427, and 2,429 kcal/kg $\mathrm{DM}$ and 2,586, 2513, and $2520 \mathrm{kcal} / \mathrm{kg} \mathrm{DM}$, respectively, using the CS method or the IC method, thus suggesting that $\mathrm{NE}$ values obtained by the CS method are about $4.6 \%$ lower than those obtained by IC. Also, in a series of studies Kil et al. (2011, 2013) reported NE values for corn, soybean oil and white choice grease that were significantly lower than published literature values that were generated using IC. For example, the NE value of corn was reported to be 1,860 $\mathrm{kcal} / \mathrm{kg}$ which was substantially lower than the values of 2,653 and 2,672 $\mathrm{kcal} / \mathrm{kg}$ reported by Sauvant et al. (2004) and NRC (2012), respectively. The differences were much larger for the lipid sources at 2,441 and 1,220 kcal/kg for soybean oil and white choice grease, respectively. Among the reasons to explain such great variance could be the estimates for retained energy measured using the two techniques, although this needs to be investigated further.

Table 1 summarizes recent NE values obtained with various determination methods.
The delay in determining the body composition in the CS technique reduces the opportunity to use data in realtime situations (Salas et al., 2012). As an alternative, a noninvasive technique; the Dual-energy X-ray Absorptiometry (DEXA) has been used to measure body composition in animals (Black et al., 2001). The DEXA methodology offers the added advantage of using the same animal over an extended period of time without any detriment to its health or performance because of a low radiation dose per scan (Salas et al., 2012). In addition the amount of time needed per scan is lower compared to the time spent on sample preparation for chemical analysis.

\section{Carbon-nitrogen balance technique}

In this technique, carbon and $\mathrm{N}$ in feed, feces, urine and gaseous output are measured on the assumption that protein and fat are the only form of energy yielding component stored in the body and that these have fixed chemical composition and enthalpies of combustion (Blaxter, 1989). The $\mathrm{C}$-balance provides the total amount of $\mathrm{C}$ retained in the body and the amount of $\mathrm{C}$ retained in fat is be calculated by subtracting the amount of $\mathrm{C}$ retained in protein as determined by the N-balance.

\section{Indirect calorimetry}

Indirect calorimetry calculates heat that living

Table 1. A summary of recently published net energy contents in feed ingredients for swine

\begin{tabular}{|c|c|c|c|c|}
\hline \multirow{2}{*}{ Ingredient } & \multicolumn{3}{|c|}{ Method for net energy determination $^{1}$} & \multirow{2}{*}{ Reference } \\
\hline & $\mathrm{CS}$ & IC & $\mathrm{PE}$ & \\
\hline Corn & 2,068 & - & - & Kil et al., 2013 \\
\hline Corn & - & - & 2,431 & Rojas and Stein, 2013 \\
\hline Corn* & - & 3,215 & - & Liu et al., 2014 \\
\hline \multicolumn{5}{|l|}{ Canola meal } \\
\hline B. napus yellow* & - & 2,103 & 1,936 & Heo et al., 2014 \\
\hline B. juncea yellow* & - & 2,342 & 2,247 & Heo et al., 2014 \\
\hline \multicolumn{5}{|l|}{ DDGS } \\
\hline \multicolumn{5}{|l|}{ Corn } \\
\hline Wheat & - & - & 2,133 & Cozannet, et al., 2010 \\
\hline Corn-wheat* & 2,410 & 2,405 & 2,367 & Ayoade, 2011 \\
\hline DESBM* & - & 2,580 & 2,530 & Velayudhan et al., 2013a \\
\hline Feather meal & - & - & 2,247 & Rojas and Stein, 2013 \\
\hline Rice & - & - & 2,662 & Kim et al., 2007 \\
\hline Soybean hulls & 603 & - & - & Stewart et al., 2013 \\
\hline \multicolumn{5}{|l|}{ Soybean meal } \\
\hline Conventional* & - & 2,466 & - & Liu et al., 2014 \\
\hline Conventional & - & - & 2,463 & Rojas and Stein, 2013 \\
\hline Fermented & - & - & 2,653 & Rojas and Stein, 2013 \\
\hline Soybean oil & 4,876 & - & - & Kil et al., 2011 \\
\hline Wheat middlings & 987 & - & - & Stewart et al., 2013 \\
\hline White choice grease & 5,900 & - & - & Kil et al., 2011 \\
\hline
\end{tabular}

DDGS, distiller dried grains with solubles; DESBM, dry extruded-expelled soybean meal; DM, dry matter.

${ }^{1} \mathrm{CS}$, comparative slaughter technique; IC, indirect calorimetry; PE, published prediction equations.

* Values reported on a DM basis. 
organisms produce by measuring their consumption of $\mathrm{O}_{2}$, production of carbon dioxide $\left(\mathrm{CO}_{2}\right)$ and $\mathrm{N}$ excreted. Animals produce heat due to metabolic reactions associated with maintenance, production (growth, milk and eggs production) and other "non-productive" functions such as physical activity, thermoregulation or immune response. Heat production is closely correlated to the amount of $\mathrm{O}_{2}$ consumed and the amount of $\mathrm{CO}_{2}$, methane $\left(\mathrm{CH}_{4}\right)$, and urinary $\mathrm{N}$ produced (Adeola, 2001). The coefficients to predict HP was derived from the complete oxidation of carbohydrate, fat and protein. The concept was based on Hess's law, according to which the heat produced in a chemical reaction is independent of the pathway between the initial and final states (Blaxter, 1989). This implies that it does not make a difference whether a substrate undergo a complete direct oxidation, or whether intermediate products such as lactic acid, fatty acids, ketone bodies are produced which are subsequently transformed and oxidized at a later stage.

Direct measurements of HP in animals require expensive installations; so usually indirect methods are used to determine HP (Christensen et al., 1988). Generally for IC technique, HP is calculated using the formula published by Brouwer in 1958 and later adapted by the "Sub-committee of Constants and Factors", published in 1965. The approach is based on $\mathrm{O}_{2}$ consumed, $\mathrm{CO}_{2}$ produced and heat released upon combustion of $1 \mathrm{~g}$ of fat, carbohydrate and protein and the method involves measurements of $\mathrm{O}_{2}$ intake, $\mathrm{CO}_{2}$ and $\mathrm{CH}_{4}$ production and $\mathrm{N}$ excretion in urine.

$$
\begin{aligned}
\mathrm{HP}= & 16.18 \times \mathrm{O}_{2}+5.023 \times \mathrm{CO}_{2} \\
& -2.17 \times \mathrm{CH}_{4}-5.989 \times \mathrm{UN}
\end{aligned}
$$

Where $\mathrm{HP}$ is in $\mathrm{kJ} ; \mathrm{O}_{2}, \mathrm{CO}_{2}, \mathrm{CH}_{4}$ in litres; $\mathrm{UN}$ is urinary $\mathrm{N}$ in $\mathrm{g}$. The $\mathrm{UN}$ corrects for the catabolism of protein and $\mathrm{CH}_{4}$ corrects for the incomplete oxidation of carbohydrates in the digestive tract that produces $\mathrm{CH}_{4}$. This method is also termed the respiratory quotient (RQ) method expressed as $\mathrm{RQ}=$ litres of $\mathrm{CO}_{2}$ produced per litres of $\mathrm{O}_{2}$ consumed, and has been used more often in reduced form (without correction for $\mathrm{CH}_{4}$ and UN) (Christensen et al., 1988) because the contribution of methane to energy (i.e. as a percentage of DE) is less than $1 \%$ (Noblet et al., 2001; Zhang et al., 2014). Another indirect method is to calculate $\mathrm{HP}$ as the difference between ME and total energy retained in the body:

$$
\mathrm{HP}=\mathrm{ME}-\mathrm{RE}
$$

Where $\mathrm{HP}=$ heat production, $\mathrm{ME}=$ metabolizable energy and $\mathrm{RE}=$ retained energy and all parameters are in $\mathrm{kJ}$. Retained energy is based on measurements of the $\mathrm{C}$ and $\mathrm{N}$ balances, assuming that all energy is retained either as fat or protein.

In general, the IC technique is a faster means of determining NE of feeds and feedstuffs with fewer animals and it can also allow repeated energy balance measurements over successive short periods of time. However, as mentioned previously, this technique requires sophisticated and costly equipment. Furthermore, various considerations are critical for the application of the IC technique, including accurate measurement of air flow rate, gas analysis and calibration of analyzers, ability to regulate temperature within animal holding chambers, and deriving the FHP.

\section{FASTING HEAT PRODUCTION IN SWINE}

The energy expended in the fasting animal is represented by the FHP. In other words, FHP is the sum of basal energy requirement and energy needed to produce available energy from body nutrient stores, and is expected to be least affected by the animal's production level (de Lange et al., 2006). In fasting, energy from body reserves is mobilized so as to produce ATP for important functions. However, normally-fed growing animals will seldom mobilize body reserves (other than glycogen) in order to supply energy for essential functions. NE systems use FHP as an estimate of the maintenance energy requirement (Noblet et al., 1994a), although a recent report has suggested that the NE requirements for maintenance can be derived from exponential regression analysis relating HP to ME intake over a range that encompasses values below and above maintenance (Zhang et al., 2014). In many of the studies in the literature, determination of FHP on nonproducing adult animals is the basis for the calculation of minimum quantity of NE, which must be supplied to the animal to keep it in energy equilibrium (Chandramoni et al., 1999). Calculated values of activity-free FHP in growing pigs vary between 700 to $800 \mathrm{~kJ} / \mathrm{kg} \mathrm{BW}^{0.60} / \mathrm{d}$ (Le Bellego et al., 2001; van Milgen et al., 2001; Le Goff et al., 2002). Several recent studies have also reported similar FHP values (e.g. Ayoade et al., 2012; Heo et al., 2014; Zhang et al., 2014).

As FHP measurements are known to be influence by a number of factors including the level of feeding prior to taking the measurements, activities, and the duration of fasting (Baldwin, 1995; Rijnen et al., 2003; de Lange et al., 2006), it is critical that these factors are carefully controlled for when estimating NE using IC.

\section{NET ENERGY SYSTEMS}

Major NE systems for pigs were developed in France (INRA), the Netherland (Centraal Veevoeder Bureau, CVB) and in Denmark. The French system of NE, which is the 
most widely used system, has been described by Noblet (2000). The system used in the Netherlands was adapted from the equations proposed by Schiemann et al. (1972). Boisen and Verstegen (1998) proposed that the NE value of pig feeds can be described in terms of the energy used for physiological functions by combining estimates for digestible nutrients and biochemical coefficients for potential ATP production from dietary nutrients. This system was referred to as the physiological energy. The French and the Dutch systems are based on NE values from animal experiments and prediction equations, whereas the Danish system is based on the potential physiological energy (PPE) released from ATP bonds at the cellular level of pigs (Stewart, 2005). However, all published NE systems for pigs combine the utilization of ME for maintenance and for growth (Noblet et al., 1994a) or for fattening by assuming similar efficiencies for maintenance and energy retention.

\section{The French system}

The system was proposed by Noblet et al. (1994a) based on a large set of measurements (61 diets). Digestible energy, $\mathrm{ME}$, and $\mathrm{NE}$ values of 61 diets were measured in $45-\mathrm{kg}$ growing Large white boars. Net energy was determined using IC technique. The amounts of DE before the end of the ileum and in the hindgut were measured for each diet. Regression equations for predicting dietary NE content was calculated and a total of 11 prediction equations were developed which can determine a correct hierarchy among feeds for both growing pigs and pregnant or lactating sows (Noblet et al., 1994a). All of these equations are based on compositional data contained in many feed tables and are applicable to single feedstuffs and mixed feeds and for pigs at any stage of production (Noblet, 2006). However, reliable data on the digestibility of energy or of nutrients is necessary for the prediction of NE content which could be a serious limiting factor for predicting energy values of pig feeds (Noblet and van Milgen, 2004).

\section{The Dutch system}

The system was developed by Central Bureau Livestock Feeding (CVB) in the Netherlands using a variation of one of NE prediction equations developed by the French system (Stewart, 2005). The system uses the concentrations of digestible nutrients in feed ingredients to estimate the NE values of feeds and feed ingredients in a way that is consistent with the French NE system (Rijnen et al., 2004). However, the Dutch system separates total digestible carbohydrates (i.e., starch and sugar) into an enzymaticallydigestible fraction and a fermentable fraction owing to differences in energetic utilization of carbohydrates between the small and the large intestine of pigs (Kil et al.,
2013).

The equations developed by the CVB are presented below:

$$
\begin{aligned}
& \mathrm{NE}_{\mathrm{CVB}}(\mathrm{kcal} / \mathrm{kg})=(28.0 \times \% \text { digestible } \mathrm{CP}) \\
& +(85.4 \times \% \text { digestible } \mathrm{EE})+(33.8 \times \% \text { starch-e }) \\
& +(30.5 \times \% \text { sugar-e })+(23.3 \times \% \mathrm{FCH})
\end{aligned}
$$

Where energy and chemical components are expressed on a DM basis; starch-e = enzymatically digestible starch, sugar-e = enzymatically digestible sugar, FCH (fermentable carbohydrates) $=$ fermentable starch (starch-f, zero value except for potato starch)+fermentable sugar (= total sugar sugar-e)+digestible NSP; digestible NSP = digestible OM digestible $\mathrm{CP}$ - digestible $\mathrm{EE}$ - starch-e $-0.95 \times$ total sugar.

\section{The Danish system}

A new concept called the PPE was proposed by Boisen and Verstegen (1998) for estimating the NE value of pig feeds. This concept was based on the combination of in vitro digestion methods for evaluating the ATP potential production from the components and biochemical coefficients for evaluating the ATP potential production from components (Noblet, 2000). The value for PPE of nutrients is the potential energy value for ATP production if digestible nutrients are completely oxidized by animals (Boisen, 2007). The PPE of different nutrients is assumed to be independent of their metabolic utilization (e.g., oxidation or retention), and as a result, the PPE calculated from various feed ingredients or digestible nutrients are additive in diets containing a mixture of feed ingredients and are independent of animal factors (Kil et al., 2013). The Danish system uses in vitro digestibility techniques to evaluate the digestibility of CP, amino acids, OM, lipids, and carbohydrates to avoid the effects of animals on nutrient digestibility. The energy value obtained is corrected for energy contribution from endogenous gut secretions. The energy values for feeds in this system are expressed as Feed Units (FU), which are calculated from the PPE values of each nutrient in the diet. The system is based on the following equation:

$$
\begin{gathered}
\mathrm{FU}_{\mathrm{gp}} \text { per kg DM }=[9.9 \times \mathrm{RDCP}+31.7 \times \mathrm{RDCF} \\
\left.+ \text { factor } \times \mathrm{IDC}+7.0 \times \mathrm{FC}-28 \times \mathrm{EUDM}_{\mathrm{i}}\right] / 7,375 \\
\mathrm{FU}_{\mathrm{gs}} \text { per } \mathrm{kg} \mathrm{DM}=[9.9 \times \mathrm{RDCP}+26.1 \times \mathrm{RDCF} \\
\left.\quad+\text { factor } \times \mathrm{IDC}+9.0 \times \mathrm{FC}-28 \times \mathrm{EUDM}_{\mathrm{i}}\right] / 7540
\end{gathered}
$$

where $\mathrm{FU}_{\mathrm{gp}}$ is feed unit for growing pig; $\mathrm{FU}_{\mathrm{gs}}$ is feed unit for gestating sow, RDCP is in vitro ileal digestible $\mathrm{CP}$, RDCF is calculated ileal digestible fat, IDC is ileal digestible carbohydrate, $\mathrm{FC}$ is fermentable carbohydrate and $\mathrm{EUDM}_{\mathrm{i}}$ is enzyme undigested ileal DM, where FU is 
expressed on a DM basis and other components are based on $\mathrm{g} / \mathrm{kg}$ DM.

\section{EVALUATION OF NET ENERGY SYSTEMS}

The French system proposed by Noblet et al. (1994a) is based on a large set of measurements and the results have been validated in some later trials (Le Bellego et al., 2001; van Milgen et al., 2001). Noblet and van Milgen (2004) when comparing other NE systems to the French system indicated that the NE Schiemann, NE Just, and NE Dutch are approximately $94 \%, 83 \%$, and $96 \%$ of the NE French, respectively, for several diets. These average differences are owing to variation in estimates of FHP and diet composition (Noblet, 2000). Net energy Schiemann and NE Dutch system underestimated diets with higher starch content, while the NE Just system underestimated diets with higher starch content and overestimated diets with higher levels of CP and dietary fiber (Noblet and van Milgen, 2004). Kil (2008), on comparing the predicted NE values from the French and the Dutch system using 16 mixed diets containing various feed ingredients found higher values from the Dutch system than those predicted from the French system. On the contrary, Kim et al. (2007) reported slightly higher NE values for cooked rice fed to weaner and growing pigs calculated using the INRA equations compared with the CVB equations. Due to the fact that the values in the French and the Dutch system were determined in standardized conditions, their application in practical conditions could result inconsistent response (Boisen and Verstegen, 1998). That was one of the reasons why the Danish system was developed. In the Danish system, there is difficulty in implementing the in vitro digestion methods and also, this approach assumes that energy is used exclusively for ATP production - which is not the case for growing pigs (Noblet, 2000).

\section{COMPARISON OF DIGESTIBLE ENERGY, METABOLIZABLE ENERGY AND NET ENERGY SYSTEMS}

One of the characteristic of an energy system is its capability to rank ingredients. Energy systems have a major influence on the hierarchy between feed ingredients (Noblet et al., 1994a; Noblet, 2000; Rijnen et al., 2004). The energy value of protein or fibrous feeds is overestimated when expressed on a DE or ME basis. On the other hand, fat or starch rich ingredients are underestimated in a DE system (Noblet et al., 1994a). These conclusions are more clearly demonstrated in studies by Noblet et al. (1993). For instance, DE values for wheat and soybean meals (3.86 and $3.91 \mathrm{Mcal} / \mathrm{kg}$ DM, respectively) were reported to be similar in studies by Noblet et al. (1993), but for NE, wheat had $34 \%$ more when compared to that with soybean meal $(2.90$ and $1.92 \mathrm{Mcal} / \mathrm{kg} \mathrm{DM}$ for wheat and soybean meal, respectively). Similarly wheat and tapioca contained quite similar DE concentration (3.86 and 3.79, respectively), whereas the NE value of tapioca was $6 \%$ higher than that of wheat (3.09 and 2.90 Mcal/kg DM, for tapioca and wheat, respectively). Likewise, the NE value of canola meal was $53 \%$ of its DE value (1.64 and $3.11 \mathrm{Mcal} / \mathrm{kg} \mathrm{DM}$ for $\mathrm{NE}$ and DE, respectively) in comparison with wheat which was $75 \%$ of its DE (2.90 and $3.86 \mathrm{Mcal} / \mathrm{kg} \mathrm{DM}$ for NE and DE, respectively).

The ratio between $\mathrm{NE}$ and $\mathrm{ME}\left(\mathrm{k}_{\mathrm{g}}\right.$ for $\mathrm{NE}$ in growing pigs) corresponds to the efficiency of utilization of ME for NE. This ratio varies according to the chemical characteristics of the feed because nutrients are not used with similar efficiencies (Birkett and de Lange, 2005). In studies conducted with growing pigs, $\mathrm{k}_{\mathrm{g}}$ was increased when fat and starch contents were higher and reduced when protein or fiber contents were enhanced (Noblet et al., 1994b).

The variation in energy losses while moving from DE to ME can be associated with the utilization of digestible crude protein (DCP) in relation with the excretion of $\mathrm{N}$ as urea (Noblet et al., 1994a). Similarly, energy losses from ME to NE can be attributed to losses as HI and for growing pigs it concerns all nutrients which is about 2.0, 1.0, 0.75, and $1.2 \mathrm{kcal}$ per $\mathrm{g}$ of DCP, digestible EE, starch and digestible fiber, respectively (Noblet et al., 1994a).

A number of growth trials conducted with variable dietary fat or CP levels has shown that the energy cost of growth or daily energy requirement are independent of diet composition when expressed on a NE basis (Noblet, 2007). On the other hand, on a DE or ME basis, the energy cost is reduced when $\mathrm{CP}$ content is lowered or fat content is increased (Sauvant et al., 2004). This shows that DE and ME overestimate the energy value of protein and underestimates the energy value of fat. As a result, unlike the NE system, the DE and ME systems are unable to predict the performance of pigs.

\section{CONCLUSION}

The dramatic shift in feed ingredient availability to the swine industry in recent years has meant that a wider range of feedstuffs must be considered in formulating swine feed, including those that contain considerable amount of fibre. Because energy is the single most expensive component of a swine diet, optimizing its utilization is critical for efficient pork production. To achieve this, it is important that the energy content in a swine feed and/or feed ingredient that is available to the pig is correctly characterized. Thus far, the 
NE system is believed to be more accurate in expressing the energy value of a feedstuff than the DE and ME systems, because DE and ME systems tend to overestimate the energy value of protein and fiber-rich feedstuffs and underestimate the energy value of fat. Also, the NE system allows for the formulation of diets that are lower in CP content and leads to reduced $\mathrm{N}$ excretion, thus minimizing the environmental impact of pork production. The net energy systems used in different parts of the world are described and compared, although the French NE system has been adopted more widely globally. Recent studies designed to characterize the NE content in distillers dried grains with solubles for swine were reviewed reported NE values range from 2,131 to $2,220 \mathrm{kcal} / \mathrm{kg}$ for corn DDGS and 2,133 to 2,396 for wheat and/or wheat-corn DDGS. Further studies on the energy content in feed ingredients for swine diets will be invaluable in accelerating the adoption of the net energy system as an important way of increasing the efficiency of pork production, especially in light the increasing scarcity of high starch ingredients.

The methods commonly used to determine the NE content of feed and feed ingredients for swine are the CS technique, IC, and published prediction equations. An argument that is often advanced when it comes to the adoption of the NE system is that the published prediction equations for estimating NE content in swine diets should suffice. Although results of some recent studies may offer support for this argument, clearly others have shown that predicted values may not always agree with empirical data. This only serves to strengthen the need for further studies on the methodologies for estimating the NE content in swine feed and feed ingredients. Also, it is our view that additional validations studies for the NE system in diets based on different feed ingredients will be useful in accelerating the adoption of this system in regions of the world where this yet to be standard practice.

\section{REFERENCES}

Adeola, O. 2001. Digestion and balance techniques in pigs. In: Swine Nutrition (Eds. A. J. Lewis and L. L. Southern). $2^{\text {nd }}$ ed. CRC Press, Washington, DC, USA. pp. 903-916.

ARC. 1981. The Nutrient Requirements of Pigs: Technical Review. Rev. ed. Commonwealth Agricultural Bureau, Slough, England. Armsby, H. P. 1917. The Nutrition of Farm Animals. MacMillan, New York, NY, USA.

Ayoade, D. 2011. Net Energy of Wheat-corn Distillers Dried Grains with Solubles for Growing Pigs as Determined by the Comparative Slaughter, Indirect Calorimetry, and Chemical Composition Methods. M.Sc. thesis, University of Manitoba, Winnipeg, MB, Canada.

Ayoade, D. I., E. Kiarie, M. A. Trinidade Neto, and C. M. Nyachoti. 2012. Net energy of diets containing wheat-corn distillers dried grains with solubles as determined by indirect calorimetry, comparative slaughter, and chemical composition methods. J. Anim. Sci. 90:4373-4379.

Bach Knudsen, K. E. 2001. The nutritional significance of "dietary fiber" analysis. Anim. Feed Sci. Technol. 90:3-20.

Bach Knudsen, K. E. and H. Jorgensen. 2001. Intestinal degradation of dietary carbohydrates - from birth to maturity in Digestive Physiology in Pigs. Proc. 8th Intl. Symp. Digestive Physiology of Pigs (Eds. J. E. Lindberg and B. Ogle), Barcelona, Spain. CABI Publishing, Wallingford, UK. p. 109120.

Bakker, G. C. M. 1996. Interaction between Carbohydrates and Fat in Pigs. Ph.D. Thesis. Wageningen University, The Netherlands.

Baldwin, R. L. 1995. Energy requirements for maintenance and production. In: Modeling Ruminant Digestion and Metabolism (Ed. R. L. Baldwin). Chapman and Hall, London, UK. p. 148188.

Baldwin, R. L. and A. C. Bywater. 1984. Nutritional energetics of animals. Annu. Rev. Nutr. 4:101-114.

Birkett, S. and K. de Lange. 2001. A computational frame for a nutrient flow representation of energy utilization by growing monogastric animals. Br. J. Nutr. 86:661-674.

Black, A., E. M. Tilmont, D. J. Baer, W. V. Rumpler, D. K. Ingram, G. S. Roth, and M. A. Lane. 2001. Accuracy and precision of dual-energy X-ray absorptiometry for body composition measurements in rhesus monkeys. J. Med. Primatol. 30:94-99.

Black, J. L. 1974. Manipulation of body composition through nutrition. Proceedings of the Australian Society of Animal Production, Sydney, Australia. 10:211-218.

Blakemore, C. and S. Jennett. 2002. The Oxford Companion to the Body. Oxford University Press, Oxford, UK.

Blaxter, K. 1989. Energy Metabolism in Animals and Man. Cambridge, Univ. Press, Cambridge, UK.

Blaxter, K. L. 1962. The fasting metabolism of adult wether sheep. Br. J. Nutr. 16:615-626.

Blaxter, K. L. and A. W. Boyne. 1978. The estimation of the nutritive value of feeds as energy sources for ruminants and the derivation of feeding systems. J. Agric. Sci. 90:47-68.

Boisen, S. 2007. New concept for practical feed evaluation systems. DJF Animal Science No. 79. Research Centre Foulum, Denmark.

Boisen, S. and M. W. A. Verstegen. 1998. Evaluation of feedstuffs and pig diets. Energy or nutrient-based evaluation systems? I. Limitations of present energy evaluation systems. Acta Agric. Scand. Sect. A Anim. Sci. 48:86-94.

Boisen, S. and M. W. A. Verstegen. 2000. Developments in the measurement of the energy content of feeds and energy utilization in animals. In: Feed Evaluation: Principles and Practice (Eds. P. J. Moughan, M. W. A. Verstegen, and M. I. Visser-Reyneveld). Wageningen Press, Wageningen, The Netherlands. pp. 57-75.

Brafield, A. E. and M. J. Llewellyn. 1982. Animal Energetics. Blackie, Glasgow, UK.

Brouwer, E. 1965. Report of subcommittee on constants and factors. In: Proceedings of the 3rd EAAP Symposium on Energy Metabolism. Troonn Publ. 11. Academic Press, London, UK. p. 441-443.

Burrin, D. G. 2001. Nutrient requirements and metabolism. In: Biology of the Domestic Pig (Eds. W. G. Pond and H. J. 
Mersmann). Cornell University Press, Ithaca, NY, USA. pp. 309-389.

Campbell, R. G. 1988. Nutritional constraints to lean tissue accretion in farm animals. Nutr. Res. Rev. 1:233-253.

Chabeauti, E., J. Noblet, and B. Carre. 1991. Digestion of plant cell walls from four different sources in growing pigs. Anim. Feed Sci. Technol. 32:207-213.

Chandramoni, C. M. Tiwari, S. B. Jadhao, and M. Y. Khan. 1999. Fasting heat production of Muzaffarnagari sheep. Small Rumin. Res. 36:43-47.

Chiba, L. I. 2000. Feeding systems for pigs. In: Feeding Systems and Feed Evaluation Models (Eds. M. K. Theodorou and J. France). CABI Publishing, Wallinford, UK. pp. 181-209.

Christensen, K., A. Chwalibog, S. Henckel, and G. Thorbek. 1988. Heat production in growing pigs calculated according to the RQ and CN methods. Comp. Biochem. Physiol. A Physiol. 91:463-468.

Close, W. H. 1996. Modelling the growing pig: Predicting nutrient needs and responses. In: Biotechnology in the Feed Industry (Eds. T. P. Lyons and K. A. Jacques). The living gut: Bridging the gap between nutrition and performance. Proc. of Alltech's 12th Annual Symposium. Nottingham University Press, Nottingham, UK. pp. 289-297.

Cole, M. 1995. Energy systems in pig feed formulation. FeedCompounder 15:18-19.

Cowieson, A. J., and V. Ravindran. 2008. Effect of exogenous enzymes in maize-based diets varying in nutrient density for young broilers: Growth performance and digestibility of energy, minerals and amino acids. Br. Poult. Sci. 49:37-44.

Cozannet, P., A. Preynat, and J. Noblet. 2012. Digestible energy values of feed ingredients with or without addition of enzymes complex in growing pigs. J. Anim. Sci. 90:209-211.

De Jong, J. A., J. M. DeRouchey, M. D. Tokach, S. S. Dritz, and R. D. Goodband. 2014. Effects of dietary wheat middlings, corn dried distillers grains with solubles, and net energy formulation on nursery pig performance. J. Anim. Sci. 92:3471-3481.

de Lange, C. F. M. and S. H. Birkett. 2005. Characterization of useful energy content in swine and poultry feed ingredients. Can. J. Anim. Sci. 85:269-280.

de Lange, K., J. van Milgen, J. Noblet, S. Dubois, and S. Birkett. 2006. Previous feeding level influences plateau heat production following a $24 \mathrm{~h}$ fast in growing pigs. Br. J. Nutr. 95:1082-1087.

Emmans, G. C. 1999. Energy flows. In: A Quantitative Biology of the Pig (Ed I. Kyriazakis). CABI International, New York, NY, USA. pp. 363-377.

Ewan, R. C. 1989. Predicting the energy utilization of diets and feed ingredients by pigs. In: Energy Metabolism of Farm Animals (Eds. Y. van der Honing and W. H. Close). Proceedings of the 11th Symposium, Lunteren, The Netherlands. pp. 215-218.

Heo, J. M., D. Ayoade, and C. M. Nyachoti. 2014. Determination of the net energy content of canola meal from Brassica napus yellow and Brassica juncea yellow fed to growing pigs using indirect calorimetry. Anim. Sci. J. 85:751-756.

Just, A. 1982. The net energy value of balanced diets for growing pigs. Livest. Prod. Sci. 8:541-555.

Kiarie, E. and C. M. Nyachoti. 2010. Effect of genotype on heat production and the net energy (NE) value of a corn-soybean meal-based diet. J. Anim. Sci. 88(E-Suppl. 3):50.

Kil, D. Y. 2008. Digestibility and Energetic Utilization of Lipids by Pigs. Ph.D. Thesis, University of Illinois, Urbana, IL, USA.

Kil, D. Y., B. G. Kim, and H. H. Stein. 2013. Feed energy evaluation for growing pigs. Asian Australas. J. Anim. Sci. 26:1205-1217.

Kil, D. Y., F. Ji, L. L. Stewart, R. B. Hinson, A. D. Beaulieu, G. L. Allee, J. F. Patience, J. E. Pettigrew, and H. H. Stein. 2013. Effects of dietary soybean oil on pig growth performance, retention of protein, lipids, and energy, and on the net energy of corn in diets fed to growing or finishing pigs. J. Anim. Sci. 91:3283-3290.

Kil, D. Y., F. Ji, L. L. Stewart, R. B. Hinson, A. D. Beaulieu, G. L. Allee, J. F. Patience, J. E. Pettigrew, and H. H. Stein. 2011. Net energy of soybean oil and choice white grease in diets fed to growing and finishing pigs. J. Anim. Sci. 89:448-459.

Kim, J. C., B. P. Mullan, D. J. Hampson, M. M. J. A. Rijnen, J. R. Pluske. 2007. The digestible energy and net energy content of two varieties of processed rice in pigs of different body weight. Anim. Feed Sci. Technol. 134:316-325.

Kleiber, M. 1975. The Fire of Life. 2nd ed. R. E. Krieger, New York, USA.

Kolstad K., U. T. Brenøe, and O. Vangen. 2002. Genetic differences in energy partitioning in growing pigs. Acta Agric. Scand. Section A Anim. Sci. 52:213-220.

Kolstad, K. and O. Vangen. 1996. Breed differences in maintenance requirements of growing pigs when accounting for changes in body composition. Livest. Prod. Sci. 47:23-32.

Le Bellego, L., J. van Milgen, S. Dubois, and J. Noblet. 2001. Energy utilization of low-protein diets in growing pigs. J. Anim. Sci. 79:1259-1271.

Le Goff, G. and J. Noblet. 2001. Comparative total tract digestibility of dietary energy and nutrients in growing pigs and adult sows. J. Anim. Sci. 79:2418-2427.

Le Goff, G., S. Dubois, J. van Milgen, and J. Noblet. 2002. Influence of dietary fiber level on digestive and metabolic utilization of energy in growing and finishing pigs. Anim. Res. 51:245-259.

Liu, D. W., N. W. Jaworski, G. F. Zhang, Z. C. Li, D. F. Li, and F. L. Wang. 2014. Effect of experimental methodology on fasting heat production and the net energy content of corn and soybean meal fed to growing pigs. Arch. Anim. Nutr. 68:281295.

Milligan, L. P. and M. Summers. 1986. The biological basis of maintenance and its relevance to assessing responses to nutrients. Proc. Nutr. Soc. 45:185-193.

Morgan, D. J., D. J. A. Cole, and D. Lewis. 1975. Energy value in pig nutrition. 1. The relationship between digestible energy, metabolizable energy and total digestible nutrient values of a range of feedstuffs. J. Agric. Sci. 84:7-17.

Myer, R.O. and J. H. Brendemuhl. 2013. 4H Project Guide: Swine Nutrition. EDIS Publication System. http://edis.ifas.ufl.edu/pdffiles/4H/4H22500.pdf Accessed October 24, 2013.

Noblet, J., H. Fortune, X. S. Shi, and S. Dubois. 1994a. Prediction of net energy value of feeds for growing pigs. J. Anim. Sci. 72:344-354.

Noblet J., X. S. Shi, and S. Dubois. 1994b. Effect of body weight on net energy value of feeds for growing pigs. J. Anim. Sci. 
72:648-657.

Noblet, J. 2000. Digestive and metabolic utilization of feed energy in swine: Application to energy evaluation systems. J. Appl. Anim. Res. 17:113-132.

Noblet, J. 2007. Net energy evaluation of feeds and determination of net energy requirements for pigs. R. Bras. Zootec. 36 (Suppl.):277-284.

Noblet, J., 2006. Recent advances in energy evaluation of feeds for pigs. In: Recent advances in Animal Nutrition 2005 (Eds. P. C. Garnsworthy and J. Wiseman). Nottingham University Press, Nottingham, UK. pp. 1-26.

Noblet, J. and J. M. Perez. 1993. Prediction of digestibility of nutrients and energy values of pig diets from chemical analysis. J. Anim. Sci. 71:3389-3398.

Noblet, J. and J. van Milgen. 2004. Energy value of pig feeds: Effect of pig body weight and energy evaluation system. J. Anim. Sci. 82(E. Suppl.):E229-E238.

Noblet, J. and X. S. Shi. 1994. Effect of body weight on digestive utilization of energy and nutrients of ingredients and diets in pigs. Livest. Prod. Sci. 37:323-338.

Noblet, J. and Y. Henry. 1993. Energy evaluation systems for pig diets: A review. Livest. Prod. Sci. 36:121-141.

Noblet, J., C. Karege, S. Dubois, and J. van Milgen. 1999. Metabolic utilization of energy and maintenance requirements in growing pigs: effects of sex and genotype. J. Anim. Sci. 77: $1208-1216$

Noblet, J., H. Fortune, C. Dupire, and S. Dubois. 1993. Digestible, metabolizable and net energy values of 13 feedstuffs for growing pigs: effect of energy system. Anim. Feed Sci. Technol. 42:131-149.

Noblet, J., L. Le Bellego, J. van Milgen, and S. Dubois. 2001. Effects of reduced dietary protein level and fat addition on heat production and $\mathrm{N}$ and energy balance in growing pigs. Anim. Res. 50:227-238.

NRC. 1998. Nutrient Requirements of Swine. 10th ed. Natl. Acad Press, Washington, DC, USA.

NRC. 2012. Nutrient Requirements of Swine. 11th Rev. ed. Natl. Acad. Press, Washington, DC, USA.

Patience, J. F, A. D. Beaulieu, R. T. Zijlstra, T. Oresanya, and R. Mohr. 2004. Energy systems for swine: A critical review of DE, $\mathrm{ME}$ and NE. Proc. Midwest Swine Nutrition Conference. Indianapolis, IN, USA.

Patience, J. F. 2005. Netting pig profit with net energy. National Hog Farmer, November 15, 2005.

Patience, J. F. and A. D. Beaulieu. 2005. The merits, benefits, and challenges of adopting the net energy system in a North American context. Minnesota Nutrition Conf., Minneapolis, MN, USA.

Payne, R. L. and R. T. Zijlstra. 2007. A guide to application of net energy in swine feed formulation. Advances in Pork Production 18:159-165.

Pettigrew, J. 2009. Effective nutrient utilization in the nonruminant animal. in Proc. 30th Western Nutr. Conf., Winnipeg, MB, Canada. pp. 47-54.

Pettigrew, J. E., G. L. Allee, J. F. Patience, H. H. Stein, D. Y. Kil, D. B. Beaulieu, and R. H. Hinson. 2009. North American swine energy system: Introduction. J. Anim. Sci. 87 (E-Suppl. 3): 97 (Abstr.)

Pond, W. G., D. C. Church, and K. R. Pond. 1995. Energy metabolism. In: Basic Animal Nutrition and Feeding. Wiley, New York, USA. p. 149-166.

Rijnen, M. M. J. A., J. Doorenbos, J. Mallo, and L. A. den Hartog. 2004. The application of the net energy system for swine. Proceedings of the 25th Western Nutrition Conference. Saskatoon, SK, Canada.

Rijnen, M. M. J. A., M. W. A. Verstegen, M. J. W. Heetkamp, and J. W. Schrama. 2003. Effects of two different dietary fermentable carbohydrates on activity and heat production in group-housed growing pigs. J. Anim. Sci. 81:1210-1219.

Rojas, O. J. and H. H. Stein. 2013. Concentration of digestible, metabolizable, and net energy and digestibility of energy and nutrients in fermented soybean meal, conventional soybean meal, and fish meal fed to weanling pigs. J. Anim. Sci. 91:4397-4405.

Salas, C., R. D. Ekmay, J. England, S. Cerrate, and C. N. Coon. 2012. Determination of chicken body composition measured by dual energy x-ray absorptiometry. Int. J. Poult. Sci. 11: $462-$ 468

Sauvant, D., J. M. Perez, and G. Tran. 2004. Tables of Composition and Nutritional Value of Feed Materials: Pig, Poultry, Sheep, Goats, Rabbits, Hhorses, Fish. Wageningen Academic Publishers, Wageningen, The Netherlands and INRA, ed. France.

Schiemann, R., K. Nehring, L. Hoffmann, W. Jentsch, and A. Chudy. 1972. Energetische Futterbevertung und Energienormen. [Energetic assessment of feeds.]. VEB Deutscher Landwirtschatsverlag, Berlin, Germany.

Shi, X. S. and J. Noblet. 1993. Digestible and metabolizable energy values of ten feed ingredients in growing pigs fed $a d$ libitum and sows fed at maintenance level; comparative contribution of the hindgut. Anim. Feed Sci. Technol. 42:223236

Stein, H. H. and G. C. Shurson. 2009. Board-invited review: The use and application of distillers dried grains with solubles in swine diets. J. Anim. Sci. 87:1292-1303.

Stewart, L. L., D. Y. Kil, R. B. Hinson A. D. Beaulieu G. L. Allee J. F. Patience J. E. Pettigrew, and H. H. Stein. 2013. Effects of dietary soybean hulls and wheat middlings on body composition, nutrient and energy retention, and the net energy of diets and ingredients fed to growing and finishing pigs. J. Anim. Sci. 91:2756-2765.

Stewart, L. L. 2005. Net Energy Values of Soybean Hulls and Wheat Middlings Fed to Growing and Finishing Pigs. MSc. Diss. South Dakota State Univ., Urbana, IL, USA.

Sullivan, Z., M. Honeyman, L. Gibson, J. McGuire, and M. Nelson. 2005. Feeding small grains to swine. Iowa State University, University Extension, PM1994 2005.

Tess, M. W. 1981. Simulated Effects of Genetic change upon Lifecycle Production Efficiency in Swine and the Effect of Body Composition upon Energy Utilization in the Growing Pig. Ph.D. Thi. Univ. of Nebraska, Lincoln, NE, USA.

Tess, M. W., G. E. Dickerson, J. A. Nienaber, J. T. Yen, and C. L. Ferrell.1984. Energy costs of protein and fat deposition in pigs fed ad libitum. J. Anim. Sci. 58:111-122.

Thacker, P. A., G. L. Campbell, and J. W. D. Groot-Wassink. 1988. The effect of beta-glucanase supplementation on the performance of pigs fed hulless barley. Nutr. Rep. Int. 38:9199. 
Thorbek, G., A. Chwalibog, and S. Henckel. 1984. Nitrogen and energy metabolism in pigs of Danish Landrace from 20 to 120 $\mathrm{kg}$ live weight. Norm for protein and energy requirements for maintenance and growth. Beretning fra Statens Husdyrbrugsforsog, 563, Copenhagen, Denmark.

Van Es, A. J. H. 1980. Feed evaluation, a survey. In: Proceedings of the Eight Symposium on Energy Metabolism Held at Churchill College, Cambridge (Ed. L. E. Mount). Butterworths, London, UK. pp. 85-94.

Van Es, A. J. H. and H. A. Boekholt. 1987. Energy metabolism of farm animals. In: Energy Metabolism in Farm Animals (Eds. M. W. A. Verstegen, and A. M. Henken). Martinus Nijhoff Publishers, Dordrecht, Netherlands. pp. 3-19.

van Heugten, E., T. C. Schell, and J. R. Jones. 2000. Principles of balancing swine rations. Pork Industry Handbook Fact Sheet, No. 7, Purdue University. pp. 1-8.

van Milgen, J. and J. Noblet. 2003. Partitioning of energy intake to heat, protein, and fat in growing pigs. J. Anim. Sci. 81(E. Suppl. 2):E86-E93.

van Milgen, J., J. Noblet, and S. Dubois. 2001. Energetic efficiency of starch, protein and lipid utilization in growing pigs. J. Nutr. 131:1309-1318.

van Milgen, J., N. Quiniou, and J. Noblet. 2000. Modelling the relation between energy intake and protein and lipid deposition in growing pigs. Anim. Sci. 71:119-130.

Velayudhan, D. E. and C. M. Nyachoti. 2014. Validation of net energy system of feed formulation in growing pigs fed barley based diets with alternative feed ingredients. J. Anim. Sci. 92 (E-Suppl. 2):645.

Velayudhan, D. E., J. M. Heo, and C.M. Nyachoti. 2013b. Effect of enzyme supplementation on the net energy content of dry extruded-expelled soybean meal fed to growing pigs. J. Anim. Sci. 91(Suppl. 2):411-412.
Velayudhan, D. E., J. M. Heo, and C. M. Nyachoti. 2013a. Net energy content of dry extruded-expelled soybean meal fed to growing pigs using indirect calorimetry. Page 187 in Energy and Protein Metabolism and Nutrition in Sustainable Animal Production - EAAP134. (Eds. J. W. Oltjen, E. Kebreab, and H. Lapierre). Wageningen Academic Publishers, Wageningen, The Netherlands.

Verstegen, M. W. A. 1971. Influence of environmental temperature on energy metabolism of growing pigs housed individually and in groups. Meded. Landbhhogerch, Wageningen, The Netherlands.

Verstegen, M. W. A. 2001. Developments towards net energy systems in feeds and animals. Proceedings of the $22^{\text {nd }}$ Western Nutrition Conference. Saskatoon, SK, Canada.

Walstra, P. 1980. Growth and Carcass Composition from Birth to Maturity in Relation to Feeding Level and Sex in Dutch Landrace Pigs. Ph.D. Thesis, Wageningen Agric. Univ., Wageningen, The Netherlands.

Wenk, C., P. C. Colombani, J. van Milgen, and A. Lemme. 2000. Glossary: Terminology in animal and human energy metabolism. In Energy Metabolism in Animals. Proceeding of the 15th Symposium on Energy Metabolism in Animals (Eds. A. Chwalibog and K. Jakobsen). EAAP publication No. 103 Snekkersten, Denmark. Wageningen Pers, Wageningen, The Netherlands. pp. 409-421.

Wiesemuller, W., S. Poppe, and W. Hackl. 1988. The energy metabolism of swine at a feed level of live weight equilibrium. Arch. Tierernahr. 38:603-617.

Woyengo, T. A., B. A. Slominski, and R. O. Jones. 2010a. Growth performance and nutrient utilization of broiler chickens fed diets supplemented with phytase alone or in combination with citric acid and multicarbohydrase. Poult. Sci. 89:2221-2229.

Zhang, G. F., D. W. Liu, F. L. Wang, and D. F. Li. 2014. Estimation of the net energy requirements for maintenance in growing and finishing pigs. J. Anim. Sci. 92:2987-2995. 